\title{
A three-dimensional finite element analysis of temperature distribution in hot mix asphalt pothole repair
}

\author{
J. Byzyka, M. Rahman \& D.A. Chamberlain \\ Brunel University, London, United Kingdom
}

\begin{abstract}
The reported research focuses on the problematic lack of durability in executed pothole repairs, much of which arises from inadequate heating of the host pavement during the repair process. A threedimensional finite-element analysis is used to model the temperature distribution in hot mix asphalt (HMA) pothole repairs. Nine pothole repair models are developed including both shallow and deep potholes. Low and high temperatures are applied to a 3D pavement structure and HMA pothole repair mix. Observations are made on (a) the effect of combinations of the existing host pavement temperature regime and that of the HMA placed to fill the pothole, (b) the rate of temperature change during process (a), and (c) the effect of pothole repair depth on temperature change following repair filling. Outcomes demonstrate that boundaries of the formed repair cool substantially faster than the central region and that repair thickness has a substantial influence on this.
\end{abstract}

\section{INTRODUCTION}

Despite good service history, asphalt pavement deteriorates with time due to repeated traffic and environmental loading, bitumen aging, weak foundation support and poor construction practices (Walker, 1984, Mfinanga et al., 1996, Adlinge \& Gupta, 2013, Lesueur \& Youtcheff, 2013, Chatti et al., 2004). Well known manifestations of asphalt pavement distresses are cracking, rutting, shoving, corrugation, depression, stripping and potholes.

Potholes are commonly one of the most severe deteriorations in asphalt pavements and decrease considerably the quality of road riding conditions. Water and repeated traffic loading are two main factors that accelerate their development. The usual pothole mode of distress includes water penetration inside the pavement through cracks of the surface course, which weaken the cohesive and adhesive bond of the asphalt mix, leading gradually from cracking to ravelling and on to the formation of potholes. Furthermore, potholes are considerably increased during the frost and freeze cycles (Adlinge \& Gupta, 2013, Lesueur \& Youtcheff, 2013).

To repair potholes in a durable manner, their causes and depth of distress should be determined and effective proper repair method chosen. Well known pothole repair methods are pothole filling and patching (Lavin, 2003). The repair process includes cutting of the asphalt layers around the pothole perimeter to form an appropriate geometry, cleaning of the pothole area from debris and water, tack coat application for proper bonding between the host and the repair material and fill with new hot mix asphalt. The last step is compaction of the new material which must be executed at no less than $79^{\circ} \mathrm{C}$ (Hughes, 1989, Commuri \& Zaman, 2008, Delgadillo \& Bahia, 2008). There may be occasions that cold asphalt mix is chosen as a pothole repair material, however, hot mix asphalt is more preferable due to its greater durability under high traffic loading (Thom, 2008, National Cooperative Highway Research Program et al., 2011).

Recent research, which includes observations on pothole repair production and detailed monitoring of them, indicates that many repairs commence failing within a short time after completion (Byzyka et al., 2016). This failure is usually caused by five main parameters named as improper transportation method, thermal segregation, inadequate compaction, insufficient bonding between the host and the new hot mix asphalt, and improper pothole geometry preparation.

To increase pothole repair performance and durability, current on-going research by the authors focuses on enhancing the interface bonding between the host pavement and the new hot mix asphalt fill. To achieve this, it is suggested to preheat the pothole excavation prior to its repair by applying infrared heating. The use of infrared technology in hot pothole repairs and repair cracking has been also stud- 
ied by Clyne et al., 2010, Uzarowski et al., 2011, Freeman \& Epps, 2012, Nazzal et al., 2014.

A route to support the above hypothesis is the understanding of temperature variations within and between the host pavement and the new asphalt fill material. To develop this understanding, a finite element (FE) model is presented in this paper. FE method is used by many researchers to study not only asphalt pavement temperatures under a variety of weather conditions but also vehicle load interaction with asphalt pavement (Melaku \& Hongshenf, n.d., Hadi \& Bodhinayake, 2003, Akbulut \& Aslantas, 2005) and other. However, thermal studies, for example, has been mainly focusing on temperature variations between the layers of a whole pavement structure and not on temperature variations during pothole repairs. This is the main point of innovation in the authors' research activity.

Hermansson (2004) developed a simulation model to predict asphalt pavement temperatures during summer and winter time. Parameters such as solar radiation, air temperature and wind velocity data were considered in the simulation. The model was validated by in-situ measurements obtained from the LTPP program USA and Sweden. The results demonstrated ability to successfully measure asphalt pavement hourly temperatures.

In 2005 Minhoto et al. developed a 3D FE model that could accurately predict asphalt pavement temperature at different depths of a pavement section located in northeast Portugal. The model was calibrated in terms of air and solar radiation measurements and validated by comparing temperature pavement measurements obtained from on-site measurements of the pavement section of interest for a period of four months.

Yang \& Liu (2007) simulated field temperature of asphalt pavement by using FE modelling. They developed a model that accurately represents a pavement structure that undergoes real weather conditions. Parameters such as stiffness modulus and coefficient of thermal expansion among others are incorporated in transient thermal analysis. Thermal stresses were calculated with results indicating that the stiffness modulus and coefficient of thermal expansion have a great influence.

Rahman et al. (2013) presented the development of a 3D FE model that simulates temperature variation at the interface of hot mix asphalt repairs. An asphalt patch example of $150^{\circ} \mathrm{C}$ mix temperature was simulated, this subjected to weather temperatures of $22^{\circ} \mathrm{C}$ and $5^{\circ} \mathrm{C}$. The simulation model demonstrated promising results. However, further research is suggested.

\section{RESEARCH OBJECTIVE}

The main research objective of the current study is to develop an FE model that reliably predicts:

1. The outcome of combining the existing host pavement temperature regime and that of the hot place repair fill material.

2. The rate of temperature change during process 1 .

3. The effect of hot mix asphalt pothole repair thickness on the regime of temperature change rate.

\section{THEORY}

When thermally analysing an asphalt pavement structure or section of it, as in the case of pothole repair hot mix asphalt, basic mechanisms of heat transfer need to be considered: radiation, convection and conduction (Kreith et al., 2012). More specifically, in an air - pavement system the heat transfer mechanisms appear as outgoing and downwelling atmospheric longwave radiation, shortwave radiation, convection due to wind and air temperature, and heat conduction within the asphalt pavement (Hermansson, 2004).

\subsection{Radiation}

Radiation is emitted by the surface of a hot body in the form of longwave radiation referred previously as outgoing longwave radiation. The equation (Equation 1) that expresses it comes from StefanBoltzman law (Solaimanian and Kennedy, 1993):

$q_{r}=\varepsilon \sigma T_{s}^{4}$

where $\mathrm{q}_{\mathrm{r}}=$ outgoing longwave radiation in $\mathrm{W} / \mathrm{m}^{2}$; $\varepsilon=$ emission coefficient, $\sigma=$ Stefan-Boltzman constant equal to $5.68 \times 10-8 \mathrm{~W} /\left(\mathrm{m}^{2} \mathrm{~K}^{4}\right)$; and $\mathrm{T}_{\mathrm{s}}=$ surface temperature in $\mathrm{K}$.

Further, the atmospheric downwelling longwave radiation is the radiation emitted by the atmosphere to the receiving body. It is expressed by Equation 2 below (Solaimanian and Kennedy, 1993):

$q_{a}=\varepsilon_{a} \sigma T_{\text {air }}^{4}$

where $\mathrm{q}_{\mathrm{a}}=$ absorbed longwave radiation in $\mathrm{W} / \mathrm{m}^{2}$; $\varepsilon_{\mathrm{a}}=$ pavement surface absorptivity and amount of clouds; and $\mathrm{T}_{\text {air }}=$ air temperature $2 \mathrm{~m}$ above the surface in $\mathrm{K}$.

Finally, shortwave radiation is the amount of radiation absorbed by the pavement surface. Hermansson (2000a, b \& 2004) has develop different approaches for its calculation.

\subsection{Convection}

According to Solaimanian and Kennedy (1993), convection can be expressed by Equation 3: 
$q_{c}=h_{c}\left(T_{s}-T_{\text {air }}\right)$

where $\mathrm{q}_{\mathrm{c}}=$ energy lost in the air in $\mathrm{W} / \mathrm{m}^{2}$; and $\mathrm{h}_{\mathrm{c}}=$ convection heat transfer coefficient that depends on surface temperature and wind velocity.

\subsection{Conduction}

In the case of heat conduction, heat is exchanged within the asphalt pavement between the host and the new hot mix asphalt. A finite difference approximation of the heat conduction equation solves the problem (Hermansson, 2004).

\section{3D FE THERMAL MODEL ILLUSTRATION}

\subsection{Simulation model}

In total, nine simulation models were created. The three different 3D assembly geometries used consisted of:

- Geometry 1: asphalt pavement having a 700mm $\mathrm{x} 700 \mathrm{~mm}$ plan area and $150 \mathrm{~mm}$ depth, with a pothole voids (host) in the center of $455 \mathrm{~mm} \times 165 \mathrm{~mm}$ plan area and depth values of $25 \mathrm{~mm}, 50 \mathrm{~mm}, 75 \mathrm{~mm}$ and $100 \mathrm{~mm}$, and

- Geometry 2: new pothole repair asphalt mix geometry of same dimensions with the host.

It is noted that dimensions of the adopted repair Geometry 2 constitute an actual minimum pothole repair area as defined by Caltrans Division of Maintenance, 2008. The 3D assembly geometries and simulation analysis were designed using CREO PARAMETRIC 3.0 and ANSYS Workbench 16.2 respectively.

The analysis used steady state thermal analysis for applying initial temperatures in the 3D assembly geometries and thermal transient analysis for simulating the thermal relationship between the host and the repair asphalt mix. The asphalt pavement section of the simulations represent the two top layers of a multilayered asphalt pavement structure named as surface course and binder course. The two layered asphalt pavement is idealized as a homogeneous, continuous, infinite in the horizontal direction and semi-infinite in the vertical direction. The depths of surface and binder courses usually range between $20 \mathrm{~mm}-50 \mathrm{~mm}$ and $50 \mathrm{~mm}-100 \mathrm{~mm}$ respectively which justifies the chosen $150 \mathrm{~mm}$ depth of the 3D asphalt pavement.

To ensure a representative model, mesh convergence test was performed for all three different 3D assemblies. For the mesh, a finer element size was adopted for the repair asphalt mix geometry. The final mesh elements, after convergence test, for the $3 \mathrm{D}$ assembly geometries are shown in Table 1. Figure 1 presents a mesh example application for $25 \mathrm{~mm}$ pothole repair depth.

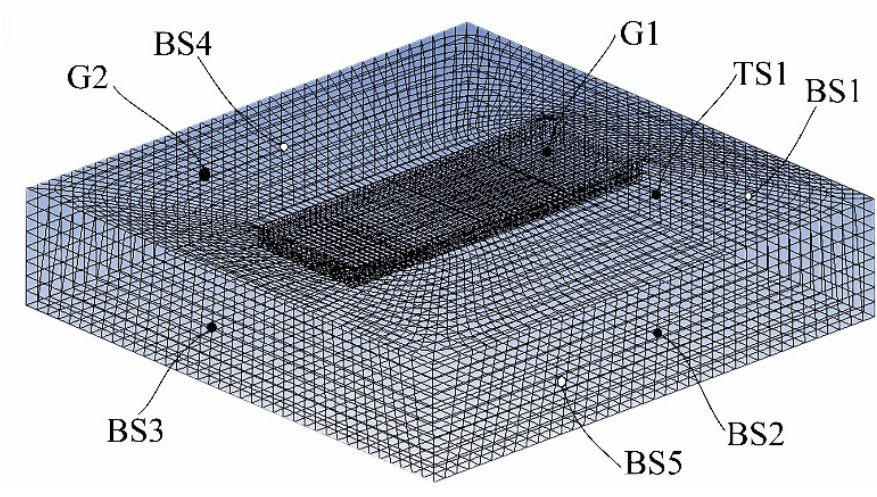

Figure 1. Mesh example application of 3D assembly geometry 1 (AG1) where G1-G2=geometry 1 \& 2 respectively, TS1=top (existing asphalt pavement) surface, BS1-BS5=boundary surfaces (of asphalt pavement).

Table 1. Mesh elements for all assembly geometries.

\begin{tabular}{ll}
\hline No & Elements \\
\hline AG1*:25mm repair depth & 38,237 \\
AG2*:50mm repair depth & 14,386 \\
AG3*: 100mm repair depth & 16,334 \\
\hline
\end{tabular}

*AG = assembly geometry

\subsection{Boundary and other conditions}

The simplified FE model of current paper represents initial body temperatures, air temperature and wind speed. Solar radiation, surface icing, rain, evaporation and condensation that many authors (see i.e. Hermansson, 2004 \& Minhoto et al., 2005) have suggested have an effect on asphalt pavement temperatures were not included.

Two boundary conditions were defined. The first is convection that represents the wind velocity and air temperature. It is applied on the top surface of the existing pavement and placed pothole repair mix (TS1 of Figure 1). The second condition was adoption of perfectly insulated boundary surfaces (BS1-5 of Figure 1) of the asphalt pavement.

Further, the weather temperature as well as the asphalt pavement and pothole repair asphalt mix temperatures were kept constant for each simulation model. The thermal properties, named as specific heat capacity and thermal conductivity, and density were also kept constant for both geometries of the simulation models.

\subsection{Material thermal properties}

Both existing host pavement and placed pothole repair asphalt mix were considered to have same hot mix asphalt (HMA) material properties given in Table 2. Therefore, possible differences in material properties between the older host asphalt mix and a new hot placed fill mix are not currently considered. 
Table 2. Material thermal properties.

\begin{tabular}{|c|c|c|c|}
\hline \multirow[t]{3}{*}{ Geometries } & \multicolumn{3}{|c|}{ Thermal properties } \\
\hline & Density & $\begin{array}{c}\text { Thermal } \\
\text { conductivity }\end{array}$ & $\begin{array}{c}\text { Specific } \\
\text { heat } \\
\text { capacity }\end{array}$ \\
\hline & $\mathrm{kg} / \mathrm{m}^{3}$ & $\mathrm{~W} / \mathrm{mK}$ & $\mathrm{J} / \mathrm{kgK}$ \\
\hline Geometry 1 & 2400 & 2 & 920 \\
\hline Geometry 2 & 2400 & 2 & 920 \\
\hline
\end{tabular}

\subsection{Simulation plan}

Nine simulation models were studied. Each model consisted of the relevant 3D assembly and was developed as already described. The simulation plan is demonstrated on Figure 2.

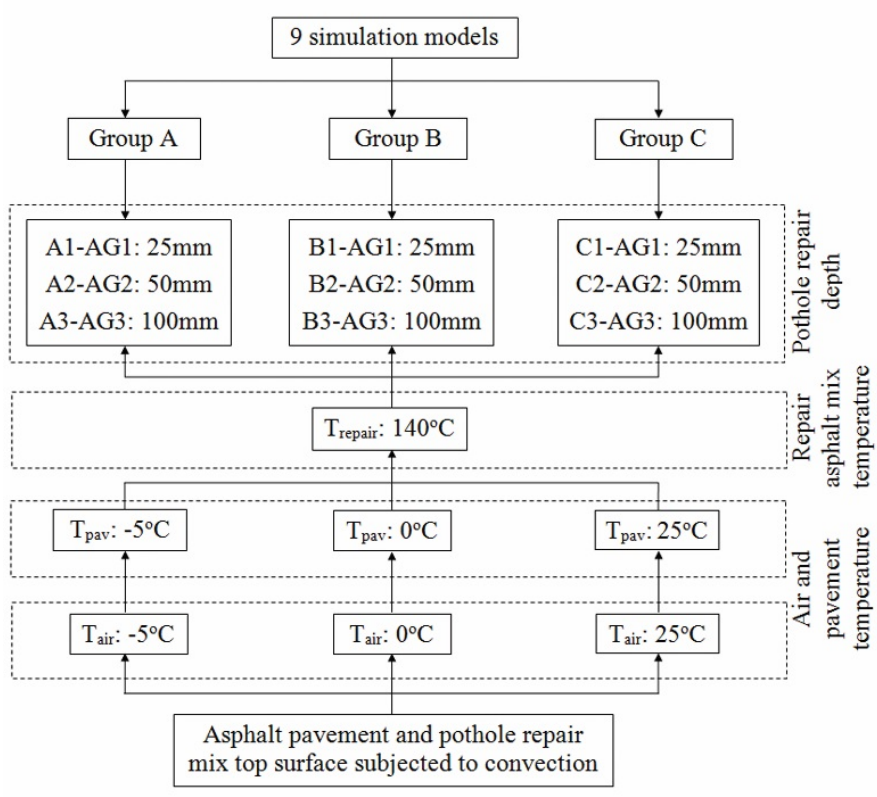

Figure 2. Simulation plan (A, B \& C=group name, $\mathrm{AG}=$ assembly geometry and $\mathrm{T}=$ temperature).

\section{RESULTS AND ANALYSIS}

Temperature measurements of nine points are presented, located on the repair mix surface and in the boundary between the host pavement and the repair mix (Figure 3). Points $1-3$ are always located in the surface of the repair mix, point 4 is located in the middle of the boundary between the host and repair mix, and points 5-9 are located in the bottom of the pothole repair. Each simulation model was run until the maximum temperature of the whole repair mix was observed to reach the cessation temperature $\left(79^{\circ} \mathrm{C}-80^{\circ} \mathrm{C}\right.$, values suggested by Hughes, 1989, Commuri \& Zaman, 2008, Delgadillo \& Bahia, 2008). This was usually seen in the middle area of the repairs simulated. Three effects were observed, all presented in the following sections.
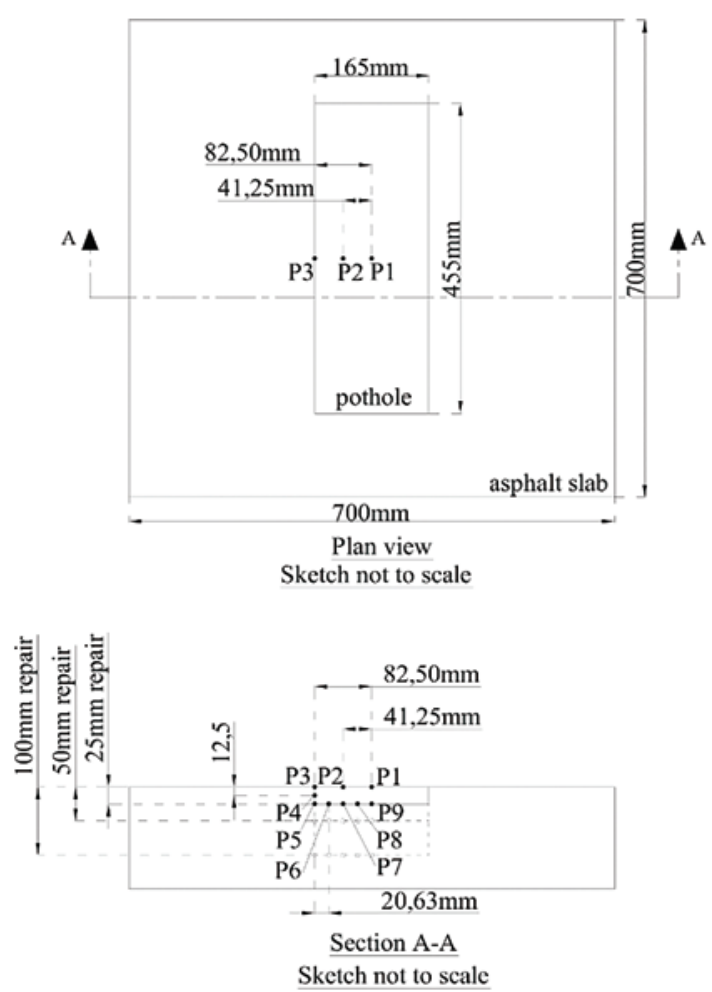

Figure 3. Demonstration of nine-point path of temperature measurements taken in the simulation models.

\subsection{Effect of existing pavement temperature to hot mix asphalt pothole repair}

Three tables (Tables 3, 4, 5) and three graphs (Figure $4,5,6$ ) are presented to demonstrate temperature variations results for $25 \mathrm{~mm}, 50 \mathrm{~mm}$ and $100 \mathrm{~mm}$ for three different asphalt pavement and weather temperatures as per the simulation plan of Figure 2. The results are related to the points of Figure 3. Their positions demonstrate low temperatures in the boundary between the host pavement and the repair mix in comparison with higher temperatures received in the middle area of the pothole repair mix on all repair depth occasions.

Table 3. Temperature variation for $25 \mathrm{~mm}, 50 \mathrm{~mm}$ and $100 \mathrm{~mm}$ related to points of Figure 3 at Tair $=-5^{\circ} \mathrm{C}$ and Tpav $=-5^{\circ} \mathrm{C}$.

\begin{tabular}{lllll}
\hline No & \multicolumn{4}{c}{ 25mm repair depth } \\
\cline { 2 - 5 } & $0.5 \mathrm{sec}$ & 50sec & 100sec & 280sec* \\
\hline Point 1 & 138.23 & 122.82 & 110.18 & 74.92 \\
Point 2 & 138.35 & 122.81 & 110.02 & 72.44 \\
Point 3 & 69.86 & 61.45 & 54.00 & 35.51 \\
Point 4 & 77.70 & 62.18 & 53.36 & 37.00 \\
Point 5 & 36.26 & 32.33 & 31.63 & 27.91 \\
Point 6 & 80.50 & 67.30 & 63.11 & 49.04 \\
Point 7 & 81.52 & 68.40 & 67.30 & 58.21 \\
Point 8 & 80.17 & 68.41 & 67.40 & 60.10 \\
Point 9 & 81.70 & 68.41 & 67.40 & 60.30 \\
\hline No & \multicolumn{4}{c}{$50 \mathrm{~mm}$ repair depth } \\
\cline { 2 - 5 } & $0.5 \mathrm{sec}$ & $50 \mathrm{sec}$ & $100 \mathrm{sec}$ & $612 \mathrm{sec}^{*}$ \\
\hline Point 1 & 141.72 & 124.3 & 118.4 & 79.27 \\
Point 2 & 139.44 & 124.2 & 118.2 & 72.03
\end{tabular}




\begin{tabular}{lllll} 
Point 3 & 70.69 & 61.76 & 58.11 & 38.11 \\
Point 4 & 88.98 & 69.58 & 66.41 & 43.66 \\
Point 5 & 34.40 & 32.06 & 32.00 & 29.51 \\
Point 6 & 82.08 & 66.06 & 63.10 & 45.87 \\
Point 7 & 85.80 & 66.76 & 67.10 & 56.44 \\
Point 8 & 86.93 & 67.21 & 67.45 & 61.20 \\
Point 9 & 83.82 & 67.67 & 67.77 & 62.47 \\
\hline No & \multicolumn{4}{c}{$100 \mathrm{~mm}$ repair depth } \\
\cline { 2 - 5 } & $0.5 \mathrm{sec}$ & $50 \mathrm{sec}$ & $100 \mathrm{sec}$ & $1060 \mathrm{sec}^{*}$ \\
\hline Point 1 & 139.84 & 124.25 & 118.5 & 78.71 \\
Point 2 & 140.50 & 124.23 & 118.3 & 69.64 \\
Point 3 & 60.91 & 59.79 & 56.82 & 39.21 \\
Point 4 & 76.31 & 66.52 & 66.81 & 54.01 \\
Point 5 & 43.36 & 31.32 & 31.57 & 31.89 \\
Point 6 & 85.74 & 66.33 & 63.23 & 46.01 \\
Point 7 & 82.40 & 66.95 & 67.19 & 56.36 \\
Point 8 & 90.36 & 67.35 & 67.59 & 62.18 \\
Point 9 & 93.78 & 67.73 & 67.88 & 63.99 \\
\hline
\end{tabular}

*Simulation end time when repair mix reached max $80^{\circ} \mathrm{C}$.

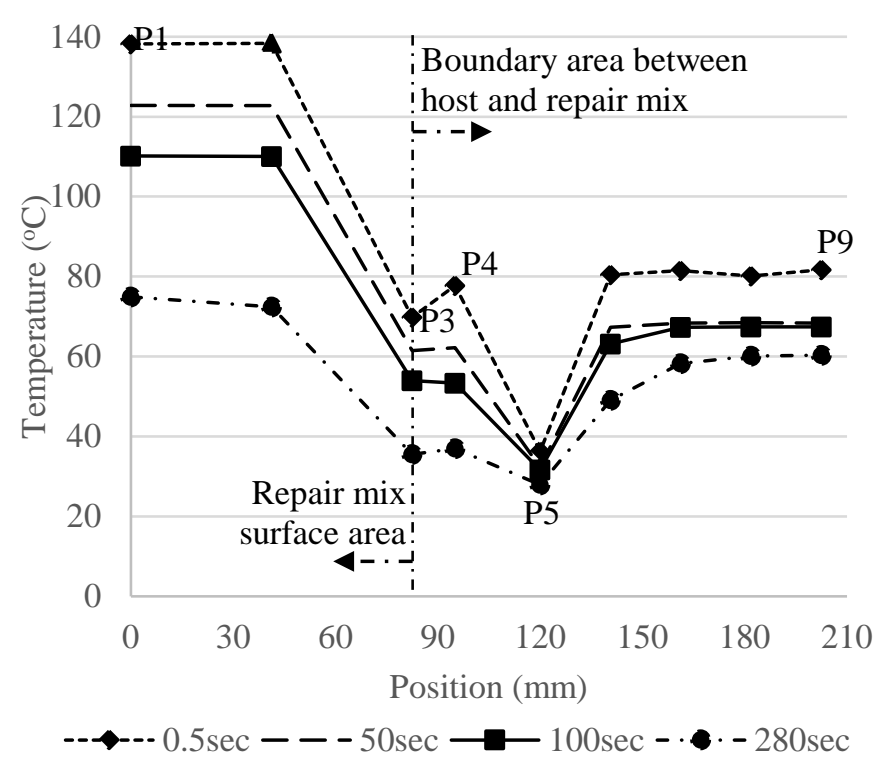

(a)

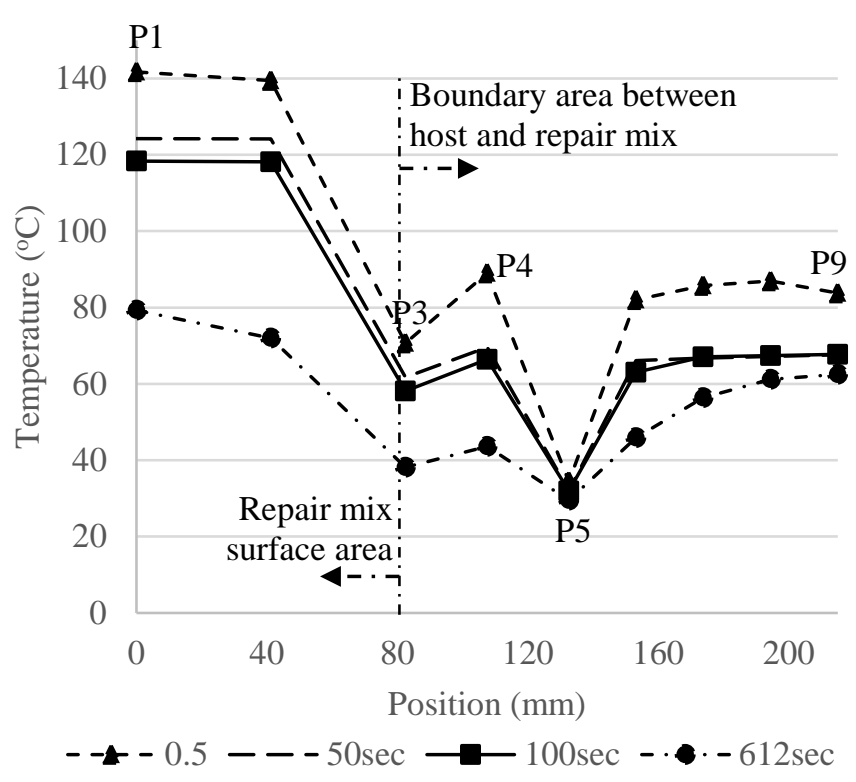

(b)

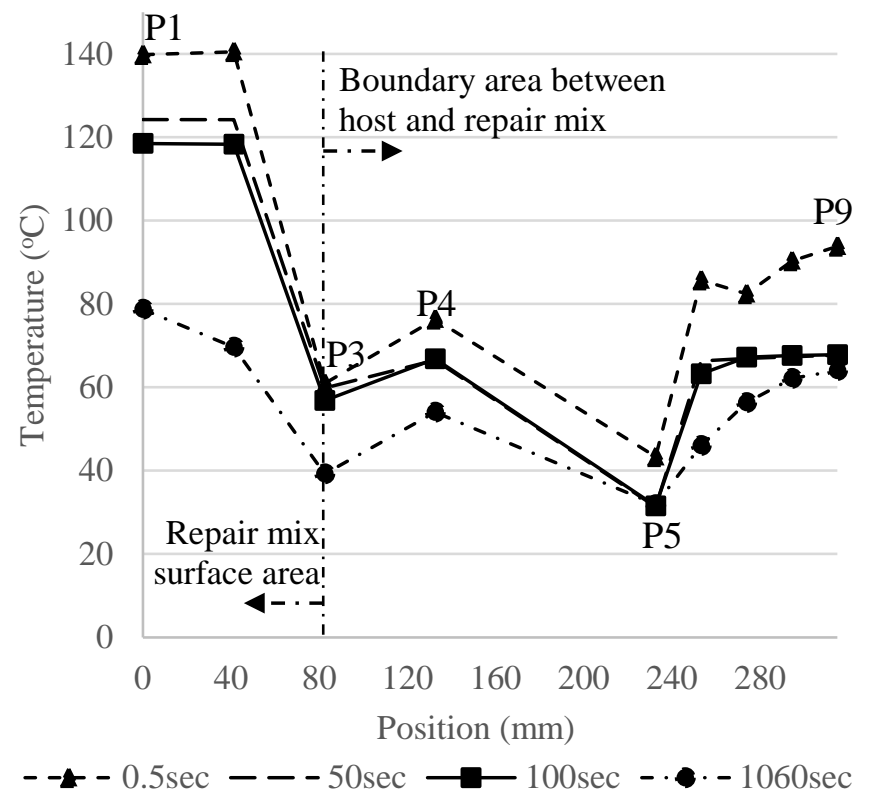

(c)

Figure 4. Graphical presentation of the effect of existing pavement temperature to hot mix asphalt pothole repair of depths (a) $25 \mathrm{~mm}$, (b) $50 \mathrm{~mm}$ and (c) $100 \mathrm{~mm}$ and at Tair $=-5^{\circ} \mathrm{C}$ and Tpav $=-5^{\circ} \mathrm{C}$.

Table 4. Temperature variation for $25 \mathrm{~mm}, 50 \mathrm{~mm}$ and $100 \mathrm{~mm}$ related to points of Figure 3 at Tair $=0^{\circ} \mathrm{C}$ and Tpav $=0^{\circ} \mathrm{C}$.

\begin{tabular}{lllll}
\hline No & \multicolumn{4}{c}{$25 \mathrm{~mm}$ repair depth } \\
\cline { 2 - 5 } & $0.5 \mathrm{sec}$ & $50 \mathrm{sec}$ & $100 \mathrm{sec}$ & $300 \mathrm{sec}^{*}$ \\
\hline Point 1 & 138.29 & 123.41 & 111.21 & 74.61 \\
Point 2 & 138.34 & 123.40 & 111.04 & 71.91 \\
Point 3 & 72.28 & 64.16 & 56.95 & 37.81 \\
Point 4 & 79.85 & 64.87 & 56.34 & 39.39 \\
Point 5 & 39.83 & 36.05 & 35.37 & 31.32 \\
Point 6 & 82.55 & 69.81 & 65.76 & 50.94 \\
Point 7 & 83.54 & 70.86 & 69.80 & 59.88 \\
Point 8 & 82.24 & 70.88 & 69.90 & 61.90 \\
Point 9 & 83.71 & 70.87 & 69.90 & 62.13 \\
\hline No & \multicolumn{4}{c}{$50 \mathrm{~mm} \mathrm{repair} \mathrm{depth}$} \\
& $0.5 \mathrm{sec}$ & $50 \mathrm{sec}$ & $100 \mathrm{sec}$ & $612 \mathrm{sec}$ \\
\hline Point 1 & 140.66 & 124.80 & 119.1 & 81.36 \\
Point 2 & 139.46 & 124.78 & 118.95 & 74.37 \\
Point 3 & 73.08 & 64.45 & 60.93 & 41.63 \\
Point 4 & 90.74 & 72.01 & 68.95 & 46.98 \\
Point 5 & 38.04 & 35.78 & 35.68 & 33.32 \\
Point 6 & 84.08 & 68.61 & 65.75 & 49.11 \\
Point 7 & 87.67 & 69.28 & 69.62 & 59.32 \\
Point 8 & 88.75 & 69.72 & 69.95 & 63.92 \\
Point 9 & 85.76 & 70.16 & 70.26 & 65.14 \\
\hline No & \multicolumn{5}{c}{$100 \mathrm{~mm}$ repair depth } \\
\hline Point 1 & 139.85 & 124.80 & 119.25 & 83.01 \\
Point 2 & 140.00 & 124.78 & 119.05 & 74.19 \\
Point 3 & 63.64 & 62.56 & 56.69 & 43.53 \\
Point 4 & 46.69 & 35.07 & 35.31 & 35.58 \\
Point 5 & 46.69 & 35.07 & 35.31 & 35.58 \\
Point 6 & 87.61 & 68.87 & 65.88 & 49.63 \\
Point 7 & 84.39 & 69.46 & 69.70 & 59.79 \\
\cline { 2 - 5 } & $0.5 \mathrm{sec}$ & $50 \mathrm{sec}$ & $100 \mathrm{sec}$ & $986 \mathrm{sec}^{*}$ \\
\hline
\end{tabular}

J. Byzyka, M. Rahman \& D.A. Chamberlain byzatd 5 
$\begin{array}{lllll}\text { Point } 8 & 92.07 & 69.85 & 70.09 & 65.36\end{array}$

$\begin{array}{lllll}\text { Point } 9 & 92.07 & 69.85 & 70.09 & 65.36\end{array}$

*Simulation end time when repair mix reached $\max 80^{\circ} \mathrm{C}$.

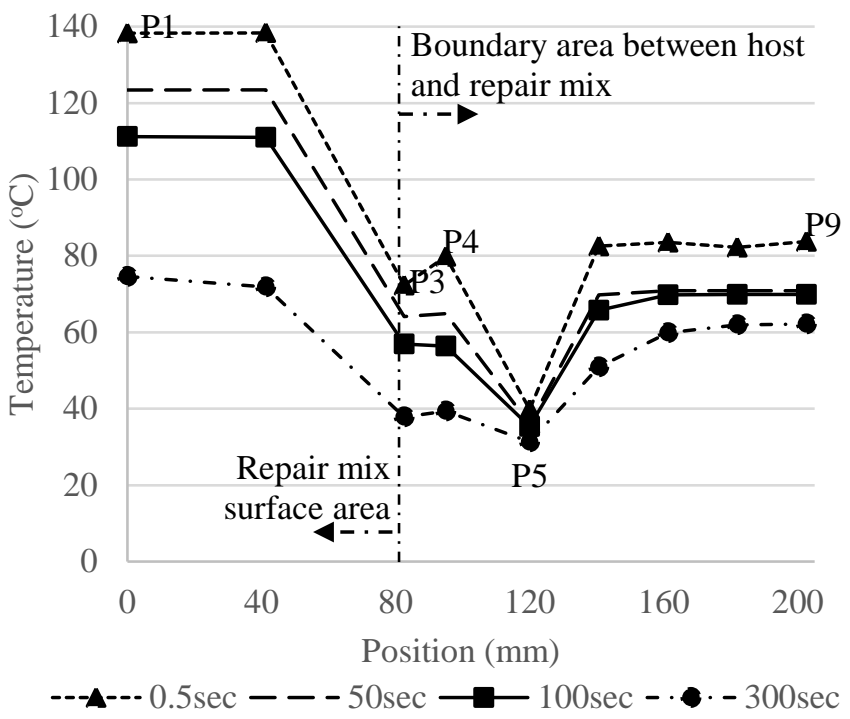

(a)

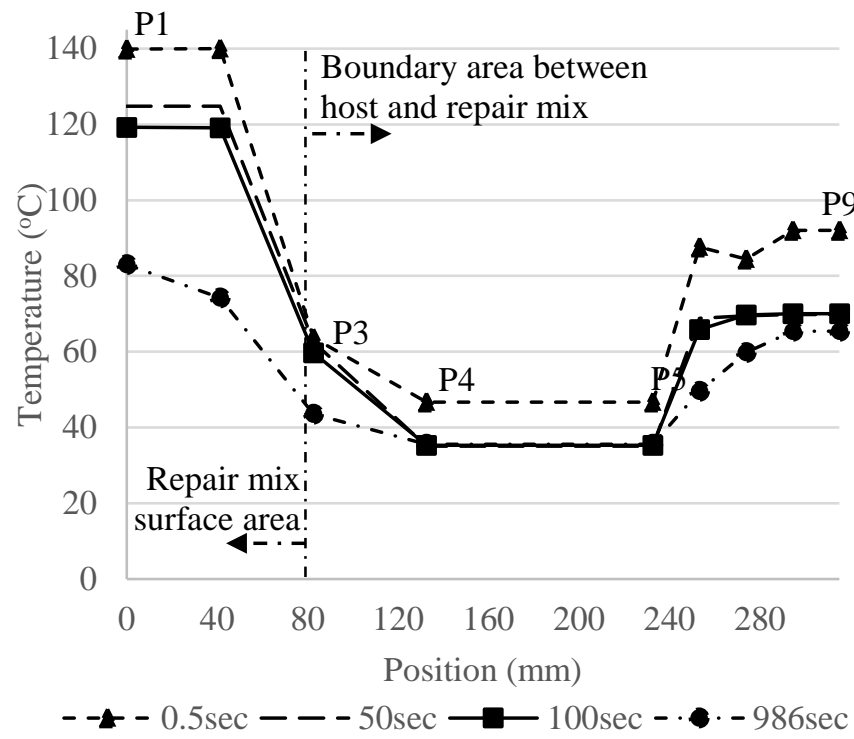

(b)

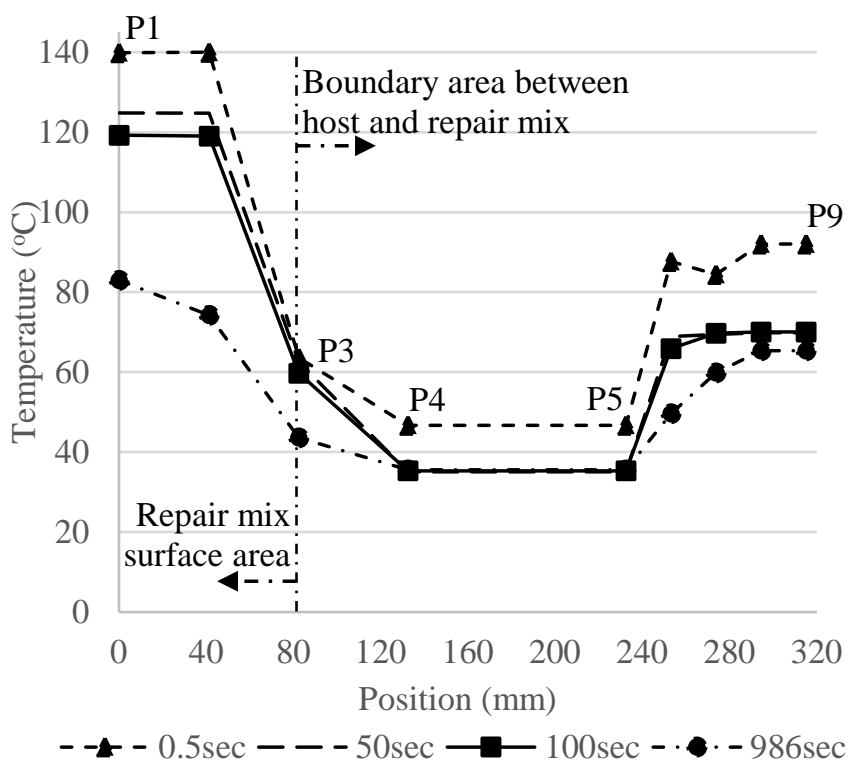

(c)
Figure 5. Graphical presentation of the effect of existing pavement temperature to hot mix asphalt pothole repair of depths (a) $25 \mathrm{~mm}$, (b) $50 \mathrm{~mm}$ and (c) $100 \mathrm{~mm}$ and at Tair $=0^{\circ} \mathrm{C}$ and Tpav $=0^{\circ} \mathrm{C}$.

Table 5. Temperature variation for $25 \mathrm{~mm}, 50 \mathrm{~mm}$ and $100 \mathrm{~mm}$ related to points of Figure 3 at Tair $=25^{\circ} \mathrm{C}$ and Tpav $=25^{\circ} \mathrm{C}$.

\begin{tabular}{|c|c|c|c|c|}
\hline \multirow[t]{2}{*}{ No } & \multicolumn{4}{|c|}{$25 \mathrm{~mm}$ repair depth } \\
\hline & $0.5 \mathrm{sec}$ & 50 sec & 100 sec & 320sec* \\
\hline Point 1 & 138.44 & 123.67 & 112.65 & 79.09 \\
\hline Point 2 & 138.48 & 123.66 & 112.51 & 76.78 \\
\hline Point 3 & 84.22 & 75.00 & 68.08 & 49.47 \\
\hline Point 4 & 90.59 & 77.97 & 70.37 & 53.82 \\
\hline Point 5 & 57.72 & 54.60 & 53.92 & 49.12 \\
\hline Point 6 & 92.81 & 82.32 & 78.88 & 64.85 \\
\hline Point 7 & 93.62 & 83.20 & 82.20 & 72.05 \\
\hline Point 8 & 92.55 & 83.21 & 82.28 & 73.80 \\
\hline Point 9 & 93.76 & 83.20 & 82.28 & 74.03 \\
\hline \multirow[t]{2}{*}{ No } & \multicolumn{4}{|c|}{ 50mm repair depth } \\
\hline & $0.5 \mathrm{sec}$ & 50 sec & 100 sec & 914 sec* $^{*}$ \\
\hline Point 1 & 141.36 & 127.51 & 122.84 & 78.86 \\
\hline Point 2 & 139.56 & 127.50 & 122.71 & 72.98 \\
\hline Point 3 & 85.03 & 77.94 & 75.05 & 53.23 \\
\hline Point 4 & 99.53 & 84.15 & 81.64 & 57.72 \\
\hline Point 5 & 56.25 & 54.39 & 54.31 & 50.57 \\
\hline Point 6 & 94.06 & 81.36 & 79.01 & 60.78 \\
\hline Point 7 & 97.01 & 81.91 & 82.18 & 68.30 \\
\hline Point 8 & 97.91 & 82.27 & 82.46 & 72.41 \\
\hline Point 9 & 95.45 & 82.64 & 82.72 & 73.68 \\
\hline \multirow[t]{2}{*}{ No } & \multicolumn{4}{|c|}{ 100mm repair depth } \\
\hline & $0.5 \mathrm{sec}$ & 50 sec & 100 sec & 1432sec* \\
\hline Point 1 & 139.88 & 127.51 & 122.95 & 82.61 \\
\hline Point 2 & 140.00 & 127.50 & 122.79 & 75.84 \\
\hline Point 3 & 77.27 & 76.39 & 74.03 & 75.83 \\
\hline Point 4 & 89.50 & 81.73 & 81.95 & 56.70 \\
\hline Point 5 & 63.35 & 53.81 & 54.00 & 67.86 \\
\hline Point 6 & 96.97 & 81.57 & 79.12 & 54.45 \\
\hline Point 7 & 94.33 & 82.06 & 82.25 & 64.03 \\
\hline Point 8 & 100.63 & 82.38 & 82.57 & 71.57 \\
\hline Point 9 & 103.35 & 82.68 & 82.81 & 76.24 \\
\hline
\end{tabular}

$*$ Simulation end time when repair mix reached max $80^{\circ} \mathrm{C}$.

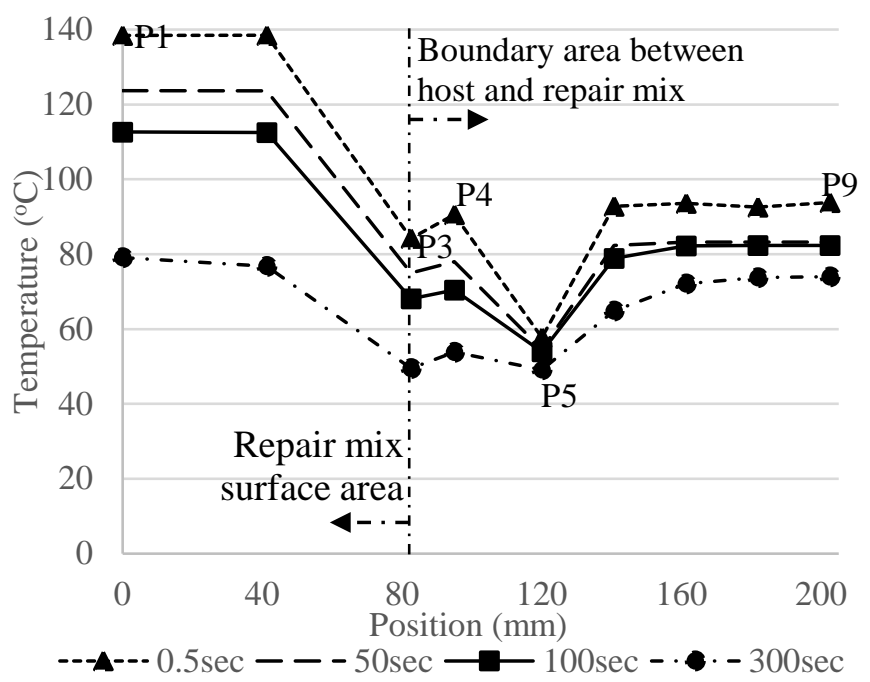

(a) 


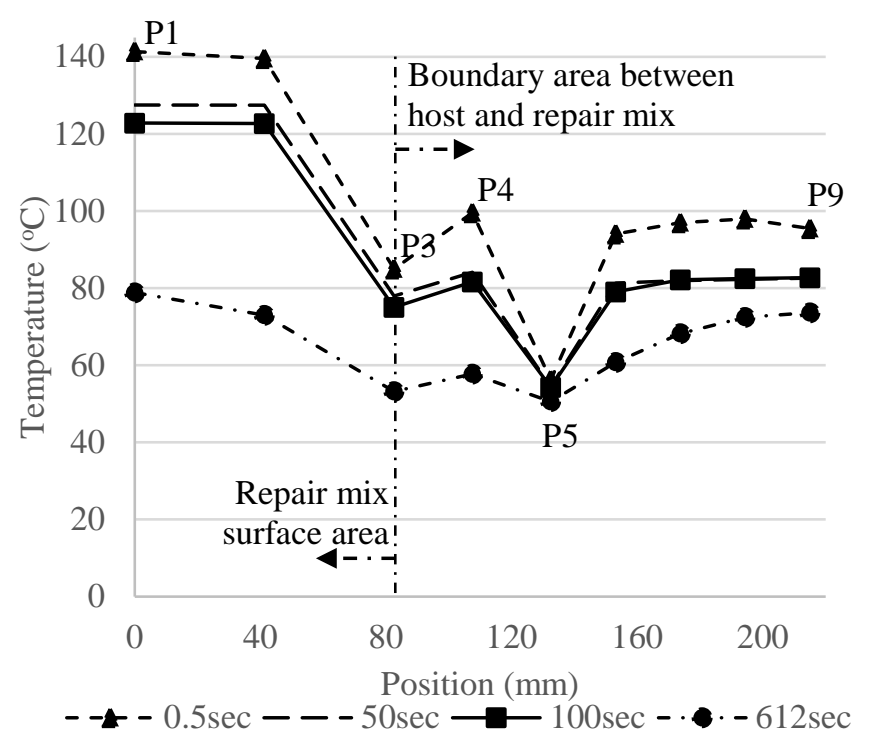

(b)

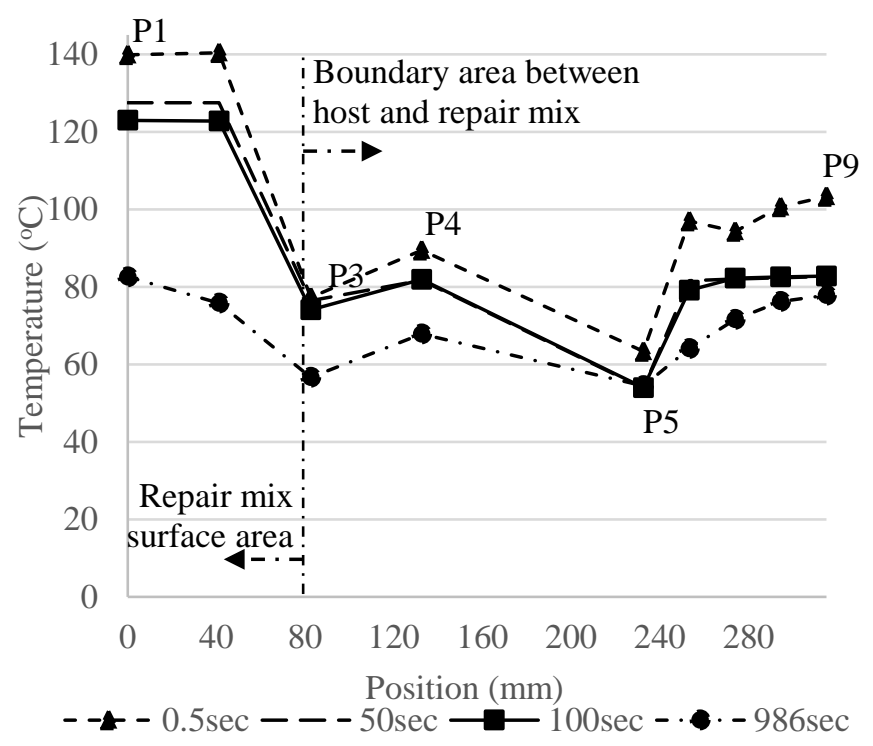

(c)

Figure 6. Graphical presentation of the effect of existing pavement temperature to hot mix asphalt pothole repair of depths (a) $25 \mathrm{~mm}$, (b) $50 \mathrm{~mm}$ and (c) $100 \mathrm{~mm}$ and at Tair $=25^{\circ} \mathrm{C}$ and $\mathrm{T}$ pav $=25^{\circ} \mathrm{C}$.

\subsection{Temperature change rate of hot mix asphalt pothole repair and the effect of repair thickness on repair temperature change rate}

The temperature change rate was observed between the examined points of section 5.1. The rate was calculated by using Newton's Law of cooling and the equation 4 final form.

$T(t)=T_{a}+\left(T_{o}-T_{a}\right) e^{-k t}$

where $\mathrm{T}(\mathrm{t})=$ the temperature at which mix falls at time $\mathrm{t}$ in ${ }^{\circ} \mathrm{C}, \mathrm{T}_{0}=$ the initial temperature in ${ }^{\circ} \mathrm{C}, \mathrm{T}_{\mathrm{a}}=$ the air temperature in ${ }^{\circ} \mathrm{C}$ and $\mathrm{t}=$ the time it takes to fall to the temperature $\mathrm{T}(\mathrm{t})$ in minutes.

Table 6 presents the time that took the point path group of each simulation model to fall to a maximum temperature of close to $79^{\circ} \mathrm{C}-80^{\circ} \mathrm{C}$ (cessation temperature). Further, Table 7 includes the calculated temperature change rate by considering an average temperature for each point path of the simulations. The results indicate the effect of the repair thickness of each assembly geometry to the temperature change rate.

Table 6. Temperature change time of all three assembly geometries (AG) until repair mix reaches an overall maximum temperature close to $80^{\circ} \mathrm{C}$.

\begin{tabular}{|c|c|c|c|c|}
\hline $\mathrm{AG}$ & $\begin{array}{l}\text { Repair } \\
\text { depth } \\
(\mathrm{mm})\end{array}$ & $\begin{array}{l}\text { Air and } \\
\text { pavement } \\
\text { temperature } \\
\left({ }^{\circ} \mathrm{C}\right)\end{array}$ & $\begin{array}{l}\text { Repair mix } \\
\text { initial tem- } \\
\text { perature } \\
\left({ }^{\circ} \mathrm{C}\right)\end{array}$ & $\begin{array}{l}\text { Temperature } \\
\text { change time } \\
\text { until } \approx 80^{\circ} \mathrm{C} \\
(\mathrm{min})\end{array}$ \\
\hline \multirow{3}{*}{ U্ব } & \multirow{3}{*}{25} & -5 & \multirow{3}{*}{140} & 4.67 \\
\hline & & 0 & & 5.00 \\
\hline & & 25 & & 5.33 \\
\hline \multirow{3}{*}{$\underset{\mho}{\mho}$} & \multirow{3}{*}{50} & -5 & \multirow{3}{*}{140} & 10.2 \\
\hline & & 0 & & 10.2 \\
\hline & & 25 & & 15.23 \\
\hline \multirow{3}{*}{$\underset{\mho}{\circlearrowright}$} & \multirow{3}{*}{100} & -5 & \multirow{3}{*}{140} & 17.67 \\
\hline & & 0 & & 16.43 \\
\hline & & 25 & & 23.67 \\
\hline
\end{tabular}

Table 7. Temperature change rate per minute.

\begin{tabular}{|c|c|c|c|c|}
\hline$A G$ & $\begin{array}{l}\text { Repair } \\
\text { depth } \\
(\mathrm{mm})\end{array}$ & $\begin{array}{l}\text { Air and } \\
\text { pavement } \\
\text { temperature } \\
\left({ }^{\circ} \mathrm{C}\right)\end{array}$ & $\begin{array}{l}\text { Average } \\
\text { temperature } \\
\text { of point } \\
\text { path } \\
\left({ }^{\circ} \mathrm{C}\right)\end{array}$ & $\begin{array}{l}\text { Temperature } \\
\text { change rate } \\
\text { per minute }\end{array}$ \\
\hline \multirow{3}{*}{ 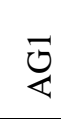 } & \multirow{3}{*}{25} & -5 & 51.41 & 0.200 \\
\hline & & 0 & 52.96 & 0.195 \\
\hline & & 25 & 64.10 & 0.715 \\
\hline \multirow{3}{*}{$\underset{4}{U}$} & \multirow{3}{*}{50} & -5 & 53.59 & 0.089 \\
\hline & & 0 & 57.34 & 0.088 \\
\hline & & 25 & 64.71 & 0.070 \\
\hline \multirow{3}{*}{$\underset{\mho}{\mathscr{Z}}$} & \multirow{3}{*}{100} & -5 & 55.30 & 0.050 \\
\hline & & 0 & 59.30 & 0.052 \\
\hline & & 25 & 68.53 & 0.041 \\
\hline
\end{tabular}

\section{CONCLUSIONS}

This study investigated the development of a 3D FE analysis that models the temperature distribution in hot mix asphalt (HMA) pothole repairs. Nine pothole repair models were developed including both shallow and deep potholes which were subjected to low and high surrounding temperatures. Temperature effects between the host pavement and the pothole repair mix were analyzed. The following were concluded:

When a hot pothole repair is executed in either summer or winter time there is a difference in temperature between the middle area of the HMA repair mix, its periphery at the top of the repair and deep in the interface between pothole excavation and hot repair. The middle area of the hot repair usually experience the concentration of higher temperatures, with the periphery at the top of the repair being much cooler. The latter suggests poor interface bonding between the pothole excavation and the HMA pot- 
hole repair, poor compaction and therefore a weak point of premature failure of the repair.

The surrounding and the host pavement temperatures as well as the depth of the hot pothole repair considerably affect both cooling time and temperature change rate. It takes more time for a deep pothole repair to cool in both hot and cold weather conditions than a shallow pothole repair with the temperature change rate being higher for the shallow pothole repair. Therefore, less compaction time is available for a shallow pothole than a deep one.

The FE Ansys thermal model showed its capability to simulate the temperature effect during a hot pothole repair in asphalt pavements. The inputted thermal properties of the asphalt mixes and mainly their thermal conductivity values should be carefully considered.

\section{REFERENCES}

Adlinge, S.S. \& Gupta, A. (2013) 'Pavement Deterioration and its Causes', International Journal of Innovative Research and Development, 2(4), pp. 437-450.

Akbulut, H. \& Aslantas, K. (2005) 'Finite element analysis of stress distribution on bituminous pavement and failure mechanism', Materials \& Design, 26(4), pp. 383-387.

Byzyka, J., Rahman, M. \& Chamberlain, D.A. (2016) 'Thermal segregation of asphalt material in road repair', Eighth International Conference on Maintenance and Rehabilitation of Pavements, Singapore, pp. 670-679.

Caltrans Division of Maintenace (2008) Maintenance Technical Advisory Guide (MTAG) Volume I - Flexible Pavement Preservation Second Edition, California Department of Transportation.

Chatti, K., Salama, H. \& El Mohtar, C. (2004) 'Effect of heavy trucks with large axle groups on asphalt pavement damage', Proc., 8th Int. Symp. on Heavy Vehicle Weights and Dimensions.

Clyne, T.R., Johnson, E.N. \& Worel, B.J. (2010) 'Use of taconite aggregates in pavement applications', Publication MN/RC - 2010-24. Minnesota Department of Transportation.

Commuri, S. \& Zaman, M. (2008) 'A novel neural networkbased asphalt compaction analyzer', International Journal of Pavement Engineering, 9(3), pp. 177-188.

Delgadillo, R. \& Bahia, H.U. (2008) 'Effects of temperature and pressure on hot mixed asphalt compaction: field and laboratory study', Journal of Materials in Civil Engineering, 20(6), pp. 440-448.

Freeman, T.J. \& Epps, J.A. (2012) 'HeatWurx Patching at Two Locations in San Antonio, Texas', Transportation Institute, Publication FHWA/TX-12/5-9043-01-1. FHWA, Texas Department of Transportation.

Hadi, M.N. \& Bodhinayake, B. (2003) 'Non-linear finite element analysis of flexible pavements', Advances in

Engineering Software, 34(11), pp. 657-662.

Hermansson, $\AA$. (2004) 'Mathematical model for paved surface summer and winter temperature: comparison of calculated and measured temperatures', Cold Regions Science and Technology, 40(1), pp. 1-17.

Hermansson, Å. (2000a) 'Frost modelling and pavement temperatures', Licentiate Thesis.Luleå University of Technology, Department of Civil and Mining Engineering, Luleå, Sweden,
Hermansson, Å. (2000b) 'Simulation model for calculating pavement temperatures including maximum temperature', Transportation Research Record: Journal of the Transportation Research Board, (1699), pp. 134-141.

Hughes, C.S. (1989) Compaction of asphalt pavement.

Kreith, F., Manglik, R.M. \& Bohn, M.S. (2012) Principles of heat transfer. Cengage learning.

Lavin, P. (2003) Asphalt pavements: a practical guide to design, production and maintenance for engineers and architects. CRC Press, Taylor and Francis Group, London and New York.

Lesueur, D. \& Youtcheff, J. (2013) 'Asphalt pavement durability', Environmental degradation of advanced and traditional engineering materials.Taylor \& Francis, Boca Raton.

Melaku, S. \& Hongsheng, Q. (n.d.) 'Finite element analysis of pavement design using ANSYS finite element code', The Second International Conference on Civil Engineering, Energy and Environment, pp. 64-69.

Mfinanga, D.A., Ochiai, H., Yasufuku, N. \& YoKOTA, H. (1996) 'Traffic Loading and Environmental Effects on Asphalt Pavement Rutting', Memoirs-Faculty of Engineering Kyushu University, 56, pp. 149-170.

Minhoto, M., Pais, J., Pereira, P. \& Picado-Santos, L. (2005) 'Predicting asphalt pavement temperature with a threedimensional finite element method', Transportation Research Record: Journal of the Transportation Research Board, (1919), pp. 96-110.

National Cooperative Highway Research Program, American Association of State Highway, Transportation Officials and Advanced Asphalt Technologies, L. (2011) A Manual for Design of Hot Mix Asphalt with Commentary. Transportation Research Board.

Nazzal, M.D., Kim, S. \& Abbas, A.R. (2014) Evaluation of Winter Pothole Patching Methods, Publication FHWA/OH2014/2. FHWA Ohio Department of Transportation.

Rahman, M., Grenfell, J., Arulanandam, S. \& Ianakiev, A. (2013) 'Influence of thermal segregation on asphalt pavement compaction', Transportation Research Record: Journal of the Transportation Research Board, (2347), pp. 7178.

Solaimanian, M. \& Kennedy, T.W. (1993) 'Predicting maximum pavement surface temperature using maximum air temperature and hourly solar radiation', Transportation Research Record, (1417).

Thom, N. (2008) Principles of pavement engineering. London: ICE Publishing.

Uzarowski, L., Henderson, V., Henderson, M. \& Kiesswetter, B. (2011) 'Innovative Infrared Crack Repair Method', 2011 Conference and exhibition of the transportation association of Canada. Transportation success: Let's build of them. 2011 Congress et Exhibition de l'Association des Transports du Canada. Les Succes en Transports: Une Tremplin vers l'Avenir.

Walker, D. (1984) 'How vehicle loads affect pavement performance', Wisconsin Transportation Bulletin.

Yang, X. \& Liu, B. (2007) 'Coupled-field Finite Element Analysis of Thermal Stress in Asphalt Pavement', Journal of Highway and Transportation Research and Development (English Edition), 2(1), pp. 1-6. 